\title{
МАТЕРИАЛЬНАЯ И ДУХОВНАЯ ДЕПРИВАЦИЯ КАК ФАКТОРЫ РЕЛИГИОЗНОЙ КОНВЕРСИИ (НА ПРИМЕРЕ ЗАПАДНОГО БУДДИЗМА)*
}

Статья посвящена исследованию роли факторов материальной и духовной депривачии в процессе религиозной конверсии на примере обращения в западныий буддизм. Постановка вопроса о значимости депривационных процессов для формирования религиозности осуществляется в рамках дискуссий о взаимосвязи депривации и религиозности, текущих дебатов о методологии исследования религиозной конверсии, а также проблематики изучения причин принятия буддизма в новых для него социокультурных ареалах. Объектом исследования выступают биографии последователей буддизма Алмазного пути, одного из наиболее распространенных в России направлений западного буддизма - варианта тибетского буддизма, ориентированного на потребности западноевропейской аудитории. В качестве методологического инструментария используется подход нарративного анализа Ф. Шютие, адаптированный к задачам исследования. В статье представлень результатьл анализа материалов биографических интервью с российскими последователями буддийских общин, проведенных в рамках полевого исследования в 20182019 году в Санкт-Петербурге, Архангельске, Северодвинске и Москве. Анализ интервью показал, что непременным условием конверсии, кроме переживания структурных и культурных лишений, является изначальная предрасположенность, интерес к буддизму. Различение в теоретической модели материальной и духовной депривации и обуславливаемых ими двух типов интеграџии в буддийскую общину, инструментального и неинструментального, позволило на эмпирическом материале реконструировать феноменологию этих типов во взаимосвязи с переживаемыми лишениями. Обнаружено, что «инструментальность» (ориентация на материальные ресурсы общины) проявляется не только на этапе активного вхождения в общину, но и сохраняется в дальнейшем как «профессионализация» в буддизме. "Неинструментальность» связана со стремлением переопределить мировоззренческие основы, чтобы совладать с жизненными трудностями, решив экзистенциальные вопросы, $u$, в конечном счете, восстановить субъективное благополучие.

Исаева Валентина Борисовна - к. социолог. н., ассоциированный научный сотрудник, Социологический институт РАН - филиал Федерального научно-исследовательского социологического центра PAН (190005 Санкт-Петербург, ул. 7-ая Красноармейская, 25/14). Эл. почта: vbisaeva@gmail.com

Дивисенко Константин Сергеевич - к. социолог. н., старший научный сотрудник, Социологический институт РАН - филиал Федерального научно-исследовательского социологического центра РАН (190005 Санкт-Петербург, ул. 7-ая Красноармейская, 25/14) Эл. почта: k.divisenko@socinst.ru

* Статья выполнена при поддержке РФФИ, проект № 18-011-00561 «Западный буддизм в России начала XXI века: анализ социального механизма религиозной конверсии». Выражаем благодарность представителям Российской Ассоциации буддизма Алмазного пути традиции Карма Кагью и нашим информантам за содействие в проведении исследования 
Ключевые слова: материальная депривация, духовная деприваџия, инструментальность, неинструментальность, социальное исключение, религиозная конверсия, западный буддизм

Ссылка при цитировании: Исаева В.Б., Дивисенко К.С. Материальная и духовная депривация как факторы религиозной конверсии (на примере западного буддизма // Вестник антропологии, 2021. № 3. С. 244-260.

\section{Введение}

Проблема объяснения религии с помощью фактора депривации волновала уже классиков социологии религии К. Маркса и М. Вебера, которые обозначили два различных ракурса анализа соответственно: структурный, подчёркивающий социально-экономическую обусловленность депривации и компенсаторную роль религии, и культурный, акцентирующий необходимость смысловой интерпретации и символической легитимации наличия различных ресурсов ${ }^{1}$. Дальнейшее обсуждение данной проблематики происходило в 1950-1960-е гг. в рамках дискуссии о религиозной инновации и динамике, участниками которой были Ч. Глок (1964), Р. Старк (1964), Б. Уилсон (1961), Р. Нибур (1957) и др. Исследователями был поставлен вопрос о разнообразии переживаемых лишений и их взаимосвязи с формированием различных типов религиозных организаций, т.е. изучение депривационной проблематики проводилось преимущественно на институциональном уровне. Необходимо отметить, что тесно связанной с вопросами религиозной инновации была дискуссия о религиозной конверсии - присоединении индивидов к одному из трёх типов религиозных сообществ - культам, сектам или инокультурным мировым религиям (в терминологии Старка и Бэйбриджа - «культурный имnopm» (Stark, Bainbridge 1996: 126-127). Именно в это время изучение религиозной конверсии начинает складываться как отдельное направление исследований со своим методологическим инструментарием, во многом междисциплинарным, включающим разработки социологии, психологии и антропологии религии. По сути, обозначенные дискуссии представляют собой две стороны одной медали, рассматривая взаимосвязь религиозности и депривации на разном уровне - институциональном и индивидуальном. В рамках изучения религиозной конверсии депривация анализировалась как один из факторов, способствующих принятию индивидом новой веры (Lofland 1965).

Начиная с 1970-х годов депривационный подход к изучению религии претерпевал период забвения и критики, в которой отмечалось отсутствие непосредственной зависимости депривации и религиозности, депривации и характера религиозной идеологии, а также позитивистский контекст, рассматривающий индивида как пассивного, того, кто подвергается структурным влияниям и обращается в веру религиозными миссионерами. Единственными социологами, которые продолжали работать над вопросом взаимосвязи депривации и религии, были Старк и Бэйнбридж (1987), рассматривавшие его на индивидуальном уровне. С одной стороны, они показали, что существование трансцендентного ядра религии обусловлено универсальной депривацией, связанной с конечными вопросами человеческого существования, с другой - так же разрабатывали проблематику дифференциации материальных лишений

Подробнее о развитии дискуссии по проблематике депривационного объяснения религиозной конверсии и религиозности см.: Исаева 2019: 39-50. 
и культурных противоречий как источника религиозности. Несомненным достижением американских социологов было указание на необходимость аналитического разделения средовых процессов, которые способствуют формированию лишений и субъективного переживания депривации.

В конце XX - начале XXI века дискуссия о взаимосвязи депривации и религиозности переживает новую волну уже в ином эмпирическом и теоретическом контексте. Движение мировых религий в глобальном пространстве, их перемещение в новые социокультурные ареалы обратило внимание исследователей на проблему культурного импорта в условиях секуляризационных и модернизационных процессов. Наиболее значимыми работами, которые способствовали возрождению этой дискуссии, стали труды Р. Инглхарта и П. Норрис (2004) и Р. Старка (2015), рассматривающие данную проблематику на социетальном уровне на материалах крупномасштабных межстрановых количественных социологических исследований. И если главным тезисом Инглхарта и Норрис является значимость материальных лишений (в их терминологии «экзистенциальной незащищённости») как фактора религиозности, то Старк настаивает на том, что именно культурные противоречия, сопутствующие быстрым модернизационным процессам, становятся причиной бурного роста религии во многих регионах мира и перемещения мировых религий в глобальном пространстве на рубеже XX и XXI веков. В целом, развитие дебатов о применимости депривационного подхода к изучению религии демонстрирует значимость фактора депривации для изучения религиозности и религиозной конверсии, однако нет единства мнений относительно ведущей роли структурных либо культурных сил для формирования религиозности.

В рамках отдельного направления исследований - изучения религиозной конверсии, учёные стремятся выработать интегративный подход к объяснению религиозной трансформации, который бы учитывал влияние различных факторов: как социально-экономических, так и культурных (Stolz 2009; 2016; Jindra 2014; Gooren 2010). В фокусе их внимания оказываются, как правило, различные направления христианства, ислама, новые религиозные движения, в то время как конверсия в буддизм остаётся малоизученной ( Үӥ 2014). Несмотря на то, что вопросам изменения буддизма в современную эпоху, особенностям его адаптации на Западе посвящено огромное количество литературы ${ }^{1}$ и сложилась дисциплина «Западный буддизм» в рамках буддологии (Prebish 2002), можно говорить о том, что предпринимались лишь отдельные попытки изучить сам процесс конверсии индивидов в буддизм, применяя соответствующий методологический подход, который позволяет вскрыть причины распространения буддизма и роста числа последователей (Gordon-Finlayson 2008; Cherry 2018).

В настоящей статье мы обращаемся к феномену западного буддизма - варианту тибетского буддизма, адаптированного к потребностям современного западного образа жизни и представленного общинами мирян под духовным руководством буддийских учителей. Начиная с середины XX века, он присутствует в социокультурном пространстве Северной Америки и Западной Европы и в 1990-е гг. на волне либерализации религиозной жизни импортируется в Россию. Учитывая результаты последних методологических достижений в исследованиях конверсии, мы рассматриваем обращение в буддизм как результат дифференцированных процессов материальной и духовной депривации, уделяя внимание как структурным предпо-

${ }^{1}$ Об этом см.: Magnone 2015. 
сылкам, формирующим депривацию - процессам социального исключения, так и её последствиям, проявляющимся в процессе интеграции в религиозную общину в определенной смысловой ориентации социального действия неофита. Цель статьи - на основе анализа интервью с последователями западного буддизма выявить характер и роль фактора депривации в процессе религиозной конверсии, определить его взаимосвязь с социальным исключением и влияние на смысловую ориентацию действия в ходе религиозного обращения.

\section{Методология исследования и данные}

Общей методологической рамкой исследования обращения в западный буддизм стал подход аналитической социологии и концепция социального механизма религиозной конверсии, соединяющая различные уровни изучения феномена (микро и макро) и учитывающая разные факторы (структурные и культурные) $)^{1}$ и вместе с тем, рассматривающая их в перспективе смысловых взаимосвязей индивида (структурный индивидуализм). Такой подход оказывается особенно актуальным для постсоветских условий, характеризующихся стремительными модернизационными процессами, ужесточением социально-экономического неравенства, противоречивым сосуществованием консервативной и различных новых идеологий в культурном пространстве.

Индивидуализация жизни с всё ускоряющимся темпом социальных изменений сопровождается переживанием депривационных процессов, предпосылки которых, с нашей точки зрения, формируются дифференцированными процессами социального исключения (Исаева 2019: 48-49; Ярошенко 2019). В то время как структурное исключение сопровождается накоплением экономических лишений, вытеснением человека с определённых социальных позиций, что ограничивает его доступ к труду и ресурсам, культурное исключение связано с изоляцией определенного жизненного опыта индивида, непризнанием различий и игнорированием интересов (Ярошенко 2019). По мнению специалистов по экономической социологии, именно процессы социального исключения приводят к переживанию депривации. С нашей точки зрения, депривационные процессы необходимо рассматривать также дифференцированно: социально-экономические лишения приводят к материальной депривации, выражающейся в невозможности следовать национальному стилю жизни, общепринятым социальным практикам выстраивать собственную жизнь в соответствии с определенными образцами потребления ввиду нехватки или сокращения ресурсов (Ярошенко 1994: 46). В свою очередь культурные противоречия заставляют индивида переживать духовную депривацию, проявляющуюся в неудовлетворённости конвенциональными ответами на экзистенциальные и моральные вопросы и поиском новых смыслов для объяснения жизни, а также принципов социального взаимодействия ${ }^{2}$.

Основная гипотеза, которая проверяется в настоящей статье, это предположение о взаимосвязи культурного исключения с духовной депривацией и неинструментальностью, предполагающей ориентацию социального действия в процессе религиозной конверсии на религиозно-символические ресурсы новой религии, и структурного исключения с материальной депривацией и инструментальностью,

\footnotetext{
${ }^{1}$ Подробнее о подходе аналитической социологии и концепции социального механизма религиозной конверсии см.: Дивисенко, Исаева 2020.

${ }^{2}$ Подробнее: Исаева 2019.
} 
предполагающей заинтересованность в материальных ресурсах. Инструментальность и неинструментальность представляют собой типы смысловой ориентации действия индивида в процессе интеграции в общину.

В качестве объекта исследования выступили биографии последователей буддизма Алмазного пути, наиболее распространенного в России направления западного буддизма. В настоящее время в России насчитывается около 100 общин ${ }^{1}$, объединённых в Российскую ассоциацию буддизма Алмазного пути традиции Карма Кагью. В процессе исследования были проведены 42 биографических интервью в городах с разным уровнем экономического благополучия - Санкт-Петербурге, Москве, Архангельске и Северодвинске. При сборе и анализе полевого материала использовался подход нарративного анализа Ф. Шютце, который был адаптирован соответственно задачам проводимого исследования и используемой методологии.

Общая стратегия анализа биографических интервью предполагала использование объяснительной триангулящии данных, применяемой в рамках аналитического подхода в социологии и совмещающая процедуры абдукции, индукции и дедукции. Первый этап анализа материалов биографических интервью - осуществление процедуры абдукции: биографические кейсы классифицируются как данные, представляющие разные типы конверсии ${ }^{2}$, т.е. разные типы изменения ценностных установок и картины мира. В процессе анализа отобранных контрастных кейсов интервью генерируются гипотезы относительно причин и факторов религиозного обращения. Второй этап анализа биографических материалов - индуктивная процедура: проверка сформулированных гипотез на других биографических кейсах. Третий этап - процедура дедукųuи: сопоставление полученных выводов с первоначальной теорией и гипотезами.

Анализ каждого отдельно взятого биографического интервью проводился по следующей схеме. Первый этап анализа биографии по методике Шютце - структурныий анализ биографического нарратива - классификация текста по типам процессуальных структур: институциональные образцы, интенциональные процессы, кривые течения, теория информанта (Рождественская 2012). Второй этап - абдуктивная прощедура, которая включала сопоставление выделенных по методике Шютце структурных единиц текста интервью с основными теоретическими категориями исследования:

а) выявление процессов структурного исключения и их следствий - ограничений материальных ресурсов и возможностей, через анализ двух видов процессуальных структур - институцииональных образцов и кривых теченийз; выявление сюжетов в биографии, сопрягаемых с нарушением нормы, через рассмотрение двух видов процессуальных структур - кривые течения, интенциональные процессыз (нарушение нормы потенциально связано с опытом культурного исключения);

${ }^{1}$ Презентационная брошюра Российской Ассоциации Алмазного пути традиции Карма Кагью, 2020. https://www.buddhism.ru/site/assets/files/1432/prezentatsiya_apkk_broshyura_blok_print_ lowres.pdf (дата обращения: 01.06.2020).

2 Подробнее о типологии религиозной конверсии на примере западного буддизма см.: Дивисенко, Исаева 2020.

${ }^{3}$ Институциональные образцы - следование нормативным правилам, связанным с общепринятыми социальными институтами (школа, армия, семья, профессиональная карьера и т.д.). Кривые течения - события и процессы в биографии, ограничивающие возможности индивида, способствующие нисходящей биографической траектории (Рождественская 2012: 113-114).

${ }^{4}$ Интенциональные процессы - инициативные действия индивида, направленные на преодоление трудностей или реализацию новых возможностей (Там же). 
б) оценка субъектных усилий, предпринимаемых информантом для преодоления процессов исключения и депривации, через анализ интенциональных процессов (что даёт возможность оценить смысловую ориентацию действия (инструментальность/неинструментальность) на этапе интеграции в общину);

в) анализ теории информанта ${ }^{l}$ с целью выявления того, как осмысляются лишения в субъективной перспективе.

На основе осуществлённой адаптации методики Шютце для анализа биографических интервью согласно задачам исследования была составлена Таблица 1.

Таблица 1

Сравнительный анализ проявления лишений и нарушения норм в процессе конверсии в западный буддизм (в биографиях респондентов)

\begin{tabular}{|c|c|c|c|c|c|}
\hline \multicolumn{2}{|c|}{$\begin{array}{c}\text { Общие сведения } \\
\text { об информанте }\end{array}$} & \multirow[b]{2}{*}{ 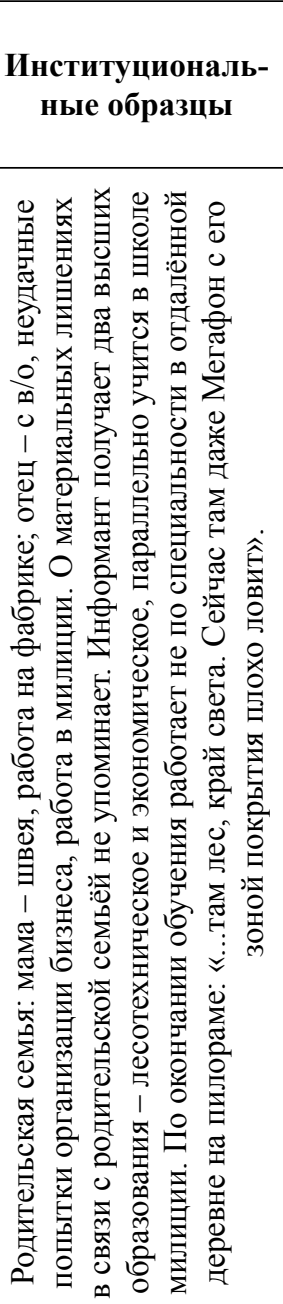 } & $\begin{array}{c}\text { Интенциональ- } \\
\text { ные процессы } \\
\text { (преодоление } \\
\text { лишений) }\end{array}$ & $\begin{array}{l}\text { Кривые } \\
\text { течения }\end{array}$ & $\begin{array}{c}\text { Теория } \\
\text { информанта } \\
\text { (осмысление } \\
\text { лишений) }\end{array}$ \\
\hline 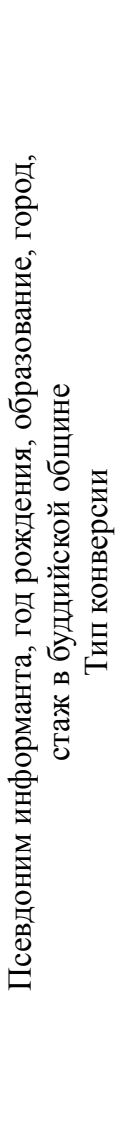 & 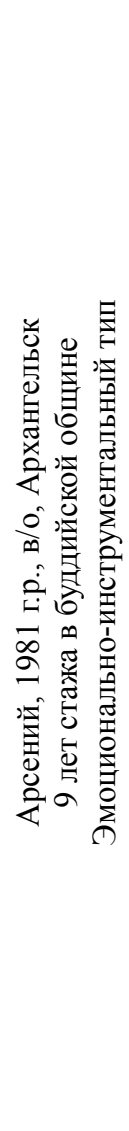 & & 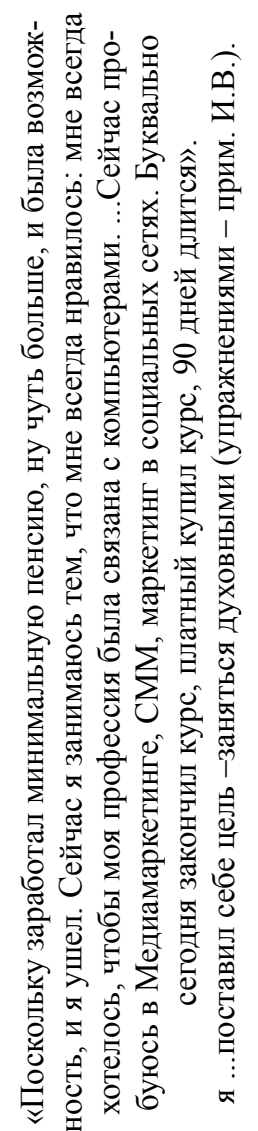 & 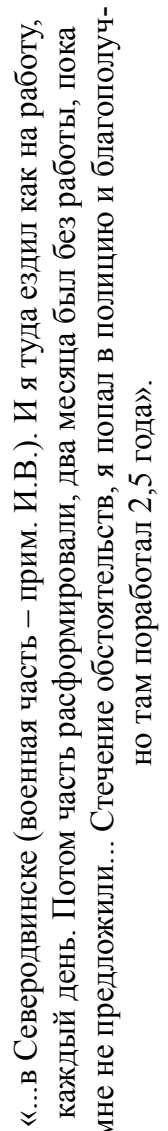 & 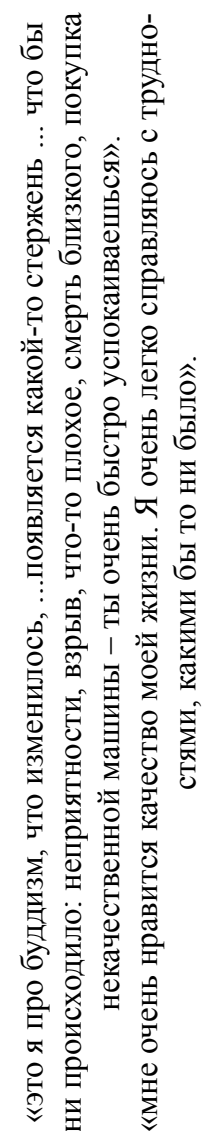 \\
\hline
\end{tabular}

При описании духовной и материальной депривации и реконструкции типов интеграции мы обращали особое внимание на неоднократно повторяющиеся (воспроизводящиеся) структуры нарратива, как правило, связанные с травмой, а также на

1 Теория информанта - интерпретация и оценка информантом своей личной истории (Рождественская 2012: 122). 
потребности и ценности информанта, которые присутствуют в его повествовании, и выявляли степень удовлетворенности духовными и материальными благами.

\section{Результаты исследования}

Согласно модели социального механизма религиозной конверсии, депривация является вторичной по отношению к исключению. Если структурное или культурное исключение определяют объективные факторы, то депривация - это переживание индивидом состояния лишений. Депривация оказывает отрицательное воздействие на восприятие качества собственной жизни (субъективное благополучие), что проявляется в наличии негативных эмоций (аффективный компонент), низкой удовлетворенности жизнью и ее отдельными сторонами, переживанием потери смысла жизни (когнитивный компонент). Именно переживание депривации, а не породившее ее исключение, оказывается ключевым фактором конверсии, определяющим принятие буддизма и интеграцию в религиозную общину.

С методической точки зрения для понимания и описания депривации как переживания необходим анализ ценностей и смыслов, репрезентируемых в жизненных историях. Это связано с тем, что даже в биографиях недавно обратившихся мы далеко не всегда можем зафиксировать непосредственное переживание (феноменологию) депривации. В силу характера интервью, мы имеем дело в подавляющем большинстве случаев с уже пережитой в той или иной мере травмой, ее отголоском. Более того, травма может умышленно или неосознанно умалчиваться в биографическом повествовании, и присутствовать только безоценочное описание социального исключения в силу болезненности воспоминаний или наоборот, его преодоления, а репрезентация жизни, несмотря на это, осуществляться в дидактическом ключе, как своего рода «история успеха». С другой стороны, воспоминание об оставшейся в прошлом депривации может оказаться сильно аберрированным и переосмысливаться с точки зрения нового мировоззрения. Пожалуй, депривация является одним из наиболее сложных для изучения феноменов в нарративах конвертитов, поскольку требует анализа субъективных комбинаций смыслов, ценностных ориентаций, потребностей, интересов, представлений и реальных возможностей индивида, пережившего депривацию.

На материалах интервью ниже мы описываем феномен духовной и материальной депривации и на основе ее следствий - смысловой направленности действия конвертитов в процессе их интеграции в религиозную общину - два типа интеграции: инструментальный и неинструментальный. В первом случае действия конвертитов, обусловленные преимущественно переживанием материальной депривации, нацелены на получение в религиозном сообществе материальных ресурсов. Во втором - связаны с духовной депривацией и ориентированы на религиозно-символические ресурсы сообщества. Перед описанием типов интеграции (конверсии), следует отметить, что они являются идеальными конструкциями, и в отдельных жизненных историях они могут преломляться, сочетаясь друг с другом, поэтому в конкретных случаях конверсии можно только утверждать присутствие того или иного типа «по преимуществу». Объединяет эти два типа, как показал анализ интервью, то, что независимо от того, находится ли человек в духовном кризисе или заинтересован определенными ресурсами буддийской общины, сам буддизм (как мировоззрение, 
учение, определенная эстетика) не вызывает у него отторжение, напротив, имеется определенная «открытость буддизму ${ }^{1} »$. Кроме предварительной предрасположенности, «открытости», на формирование положительного отношения к буддизму оказывает влияние и наличие друзей-буддистов, их позитивный образ и общение с ними.

\section{Неинструментальный тип интеграции}

Социальное исключение порождает жизненный опыт, осмысление и переживание которого невозможно или крайне затруднено в пространстве привычных мировоззренческих координат. Как показал анализ различных случаев, духовная депривация может сопровождать и материальную, вызванную структурным исключением, либо появляться независимо от нее - при относительно удовлетворительном уровне материального благополучия. Значимыми лишениями, определяющими культурное исключение, оказываются жизненные коллизии, связанные с нарушением гендерных норм и с изменениями представлений о мужских и женских ролях, что крайне осложняет или делает невозможной реализацию собственных жизненных стратегий. Культурное исключение также связано с нарушением семейных норм - определённых ожиданий со стороны родителей относительно профессиональной или брачной траектории детей. Нарушение гендерных и/или семейных норм формирует травматичный жизненный опыт и вынуждает индивида искать новые символические ресурсы, которые могут не только компенсировать травму, но и открыть возможности для переосмысления собственной жизни.

Неинструментальный тип интеграции в общину как следствие культурного исключения более психологизирован, чем инструментальный. Его движущая сила поиск и переопределение мировоззренческих основ, стремление совладать с жизненными трудностями, решить экзистенциальные вопросы, в конечном счете, восстановить субъективное благополучие.

Затянувшееся переживание духовной депривации и у мужчин, и у женщин часто заставляет их искать ответы на вопросы в изучении психологии, а также интересоваться или даже глубоко погружаться в эзотерику, восточную духовность. Христианство, в частности, православие (преимущественно как мировоззренческая и этическая система) тоже часто оказывается востребованным, однако не может вполне удовлетворить их запросы.

Как правило, информанты осознают, что к буддизму их подвели негативные события - «испытания», «кризис», ощущение, что «всё какое-то бессмысленное», проблемы, связанные с этическими вопросами, накопившимся грузом психологических проблем. Вместе с тем они осознают и говорят в интервью о своей непохожести на других людей, в частности, членов своей семьи («я всегда была какой-то такой в семье... отдельным персонажем»), а также отмечают осознанное нежелание быть как все, жить усредненной жизнью («мне кажется, это изначально был интерес к чему-то такому необычному, не просто прожить жизнь, как многие люди проживают: дом, работа, семья...»). Интуитивный (нерефлексируемый) интерес к буддизму подвигает их к началу активной интеграции в общину, но, вместе с тем, сохраняется и критическое отношение («пошёл я не сразу, естественно были сомнения») и предубеждение о самой организации, сформированное, очевидно, благодаря общему религиозному контексту постперестроечной эпохи.

\footnotetext{
1 Этим понятием буддисты обозначают предрасположенность человека к восприятию учения.
} 
Как правило, не испытывая материальных лишений на этапе вхождения в общину, представители данного типа стремятся к решению своих собственных духовных, психологических проблем. Кризис, связанный с их острым переживанием, может в интервью умалчиваться, а о его наличии можно утверждать только по косвенным свидетельствам. Именно имевшиеся в прошлом нерешенные проблемы (не только психологические, но и семейные) приводят к экзистенциальному кризису - обессмысливанию жизни. Переживание своего несоответствия ожиданиям со стороны значимых других проявляется в виде депрессивных симптомов. Обращение в буддизм и начало духовных практик для них оказывается своего рода терапией. Более того, параллельное изучение учения и его практическое применение в большинстве случаев отвечает на актуальные мировоззренческие вопросы, позволяет совладать с эмоциями, решить психологические проблемы, повысить самооценку. Свою лепту вносит также и сообщество практикующих, культура «посиделок» после медитаций, когда становится возможным совместное обсуждение проблем, моральная поддержка друг друга. В этих случаях буддийское учение имеет для индивида, как правило, компенсирующий характер. Так, нами было зафиксировано состояние, близкое «персональной депривации» ${ }^{1}$, которую определяет лишение непосредственной духовной Встречи с близкими и значимыми людьми (Баранников 2010: 70). Не ставя цели определения психологической основы конверсии, можно в целом отметить, что «разочарования» в отношениях с людьми, потребность в духовной встрече со значимым Другим, могут, наряду с другими факторами культурного исключения, оказываться причинами духовного поиска, приводящими к принятию буддизма.

Кроме того, буддийское учение при духовной депривации может иметь и ресурсный характер. Например, в объяснении одним информантом собственной конверсии подчеркивается его стремление к поиску «нового», «своих принципов», в конечном счете, собственной идентичности и индивидуальной профессионально-творческой траектории, чему, по его мнению, отвечает это учение. Ориентация на буддизм также формируется из-за стремления подражать субъективно значимым авторитетам: «если взять современных художников... современных, я имею в виду XX-XXI век... то они так или иначе связаны с буддизмом».

Отмечаемый информантами «интерес», обозначающий осознаваемую и репрезентируемую информантом в интервью изначальную направленность и предрасположенность к восприятию буддизма, зачастую оказывается конституирующей биографический нарратив структурой. В силу этого репрезентация материальной или духовной депривации в рассказе может быть сглажена либо вовсе отсутствовать, уступая место описанию духовного поиска ${ }^{2}$. Так, репрезентация жизненного пути, определяемого духовным поиском, представляет собой глубоко осознанный, отрефлексированный, с выраженным внутренним локусом контроля биографический проект, ориентированный на постановку и достижение целей, связанных с поиском ответов на экзистенциальные, мировоззренческие вопросы. Для представителей первой волны буддистов духовный поиск мог определяться не только и не столь-

\footnotetext{
${ }^{1}$ Понятие «персональная депривация» и описание этого состояния как вида духовной депривации предложено проф. А.С. Баранниковым (Баранников 2010).

2 Духовный поиск (поисковая религиозная ориентация) характеризуется направленностью человека на раскрытие экзистенциальных вопросов, лишенной религиозного буквализма и догматизма, а также готовностью принимать новое и пересматривать имеющиеся убеждения. См. подробнее (Ясин 2016: 56-58).
} 
ко индивидуальным измерением, сколько духом времени - атмосферой 1980-х гг. В воспоминаниях они подчеркивают своё «взаимодействие с диссидентским движением», подчеркивая значимость для себя людей, которые «ищут смысл жизни». На своем пути они, как правило, миновали, испытав на себе, различные духовные учения и практики (разного рода эзотерику, восточные культы, влияние отдельных персоналий - Ошо, Кастанеды и др.). Остановка духовного поиска на буддизме у наших информантов была обусловлена, в том числе и фигурой Ламы ${ }^{1}$. Для них было важно найти учителя, руководителя, своего рода «духовный образец», который не только излагает учение, но и воплощает его. Вместе с тем неугасающий духовный поиск и в рамках уже принятого буддизма порождает своего рода духовные девиации от принятых и благословляемых Ламой норм, что проявляется в расширении круга практик (например, медитация на Белую или Зеленую Тару), контактах с другими духовными учителями и представителями различных школ буддизма.

Итак, принятие буддийского мировоззрения оказывается для наших информантов выходом из депривационной ситуации: новые, принятые из буддийского учения категории позволяют переосмыслить не только понимание экзистенциальных, этических вопросов, но и житейские темы - финансовый достаток, понимание счастья, болезни и смерти, партнерских взаимоотношений, нестабильность работы. На повседневном уровне информанты фиксируют у себя изменение восприятия ситуации, отстранение от того, что раньше воспринималось как само собой разумеющееся, развитие рефлексивности («просто видишь картину в целом»), которая всегда имеет для них положительное значение.

\section{Инструментальный тип интеграции}

Инструментальная направленность в момент интеграции в общину у конвертита появляется, как правило, при переживании материальной депривации и вытекающей из нее фрустрации от невозможности придерживаться определенного стиля жизни, который оказывается недостижимым из-за низкого уровня материального благополучия, являющегося следствием структурных ограничений.

К инструментальному характеру конверсии у старшего поколения буддистов предрасполагали не только индивидуальные факторы - переживание материальных трудностей, которые испытывало большинство населения в 1990-е годы, но и активное развертывание сети буддийских центров в РФ. Опыт организации центров, их непосредственного строительства (ремонта и оформления помещения), переводов и издания книг для многих представителей старшего поколения оказался возможностью для расширения своей профессиональной траектории. Полученные знания, навыки, опыт активно использовались ими не в только в рамках буддийского сообщества, но и за его пределами.

Как показали проведенные интервью, у ряда информантов инструментальный характер проявился не только на этапе вхождения в общину, но и остался после завершения конверсии. Это явление можно обозначить категорией in vivo - «профессионализацияя», под которой понимается связывание индивидом собственной профессиональной траек-

\footnotetext{
${ }^{1}$ Харизматическим лидером и фактическим организатором глобальной сети буддийских центров Алмазного пути является датчанин, Лама Оле Нидал. Центры буддизма Алмазного пути представляют традицию тибетского буддизма школы Карма Кагью и находятся под духовным руководством Кармапы XVII Тринле Тхайе Дордже.
} 
тории или большей части трудовой деятельности с буддизмом и/или сангхой. Так, один из наших информантов, с начала 90-х годов оставив творческую профессию, занимался организацией приездов Ламы Оле в Россию, организовал буддийский центр в родном городе, в дальнейшем, получив образование в Индии и освоив тибетский язык, занимался организацией туров в Индию, Тибет, переводческой деятельностью, подготовкой научных изданий, съемками документального фильма о буддизме. Вместе с тем, он считает, что «профессионализация», которая в целом не приветствуется Ламой Оле, невозможна, когда на первом месте стоит обогащение: «... те, кто рассчитывают заработать на дхарме, обречены на неудачу. Я много раз видел эту ситуацию».

Если же говорить не о случаях «профессионализации», то инструментальность большей частью связана с участием в строительстве буддийских центров, ступ, «стройритритах», в организации приездов Ламы в Россию, резидентством (проживанием) в центрах, что может помогать решать временные трудности с поиском работы, отсутствием жилья. Активно используются для этих же целей социальные связи внутри общин при переездах и обустройстве в новом месте. Как было отмечено нашим информантом, «кто-то постоянно помогает в ситуациях... ты приходишь и какую-то пользу извлекаешь». Изменившиеся экономические условия в начале нынешнего столетия, рост материального благополучия, как объективные факторы, изменили и рынок занятости в сангхе: участие в стройке стало замещаться резидентством. У части членов общин появилась возможность принимать участие не только в строительстве, но и оказывать финансовую поддержку разным проектам (строительным, организационным, выставочным, культурным).

Одним из возможных индикаторов инструментального характера конверсии является наличие в биографии буддиста миграции. Миграция «по буддийской линии» осуществляется с привлечением ресурсов принимающего сообщества, хотя часто и не обусловлена именно религиозными мотивами. Такого рода инструментальность иногда бывает непросто заметить в интервью, даже сопоставляя миграционные передвижения с моментом конверсии.

Весьма показательна история жизни молодой буддистки, которая после окончания школы училась в частном христианском религиозном образовательном учреждении, нисколько не восприняв евангельского христианства: «Мне нравились эти люди, что они, в отличие от православных... они умели радоваться. Они собирались, пели песни, делали какие-то вечеринки. <...> Они играли... этот их рок христианский. Конечно, они собирались, молились. Я с ними тоже сидела, молилась. Когда колледж закрывали, мы совместно молились. Но когда они говорили «Бог, Бог»... мне было смешно. Не знаю. Я понимала, что это что-то хорошее и важное, но как таковой Бог, Отец, Иисус... они вот говорили «Иисус» постоянно. А у меня это никак не отзывалось. Я не стала верить». При высокой степени лояльности к самой организации, постоянном общении с христианами, религиозное обращение у информантки не произошло, так как, по ее словам, ей была более близка эзотерика. Конверсия в буддизм состоялась через несколько лет в иных обстоятельствах при устройстве на новую работу и романтических отношениях с сотрудником-буддистом, чему предшествовали непростые жизненные обстоятельства: отсутствие работы, наличие долгов, нехватка финансовых средств. Вместе с постепенной интеграцией в общину она начала ездить в разные города, буддийские центры, на различные курсы, достаточно часто меняя место жительства. На этом примере особенно четко видно, что религи- 
озная конверсия происходит в период переживания материальной депривации, однако определяется не только ей - важную роль играет «открытость» именно буддизму.

В целом, следует уточнить, что инструментальность, особенно у молодого поколения буддистов, выражается не только и не столько в получении материальных благ (жильё, еда, деньги), сколько в достижении собственных целей в контексте буддизма. Ими могут быть самореализация, удовлетворение собственного интереса - изучение восточной культуры, иностранных языков, выстраивание профессиональной траектории, поиск партнера/супруга (супруги), создание семьи. Приоритет ценностей развития, самореализации, самоутверждения (при всём различии интенций) порождает, как было отмечено выше, религиозный поиск, не связанный с депривационными механизмами, и является индикатором инструментального характера интеграции в буддийское сообщество. Кроме того, можно говорить о «социальной» инструментальности, которая представляет собой замещение фрустрации, вызванной депривацией, активной социальной вовлеченностью: происходит компенсация материальных ограничений через социальные практики в общине. В нарративах это проявляется как превалирование значимости социального, а не практического измерения религиозности: «и это связано не столько с тем, что... мне нужно помедитировать. А просто заходил в Центр, когда у тебя встреча активная, обмен информацией с людьми».

\section{Заключение}

Проведенное исследование показало, что и материальные лишения, и культурные противоречия способны выступать условиями конверсии в западный буддизм в современной России. Необходимость учитывать дифференцированный характер депривации и социального исключения, а также разные уровни формирования и переживания лишений обусловили применение интегративного подхода к исследуемому феномену. Адаптация методики нарративного анализа интервью Шютце в рамках приёма объяснительной триангуляции данных для рассмотрения процесса религиозной конверсии позволила выявить характер и роль фактора депривации в процессе религиозной трансформации в контексте конкретной личной истории, проследить его взаимосвязь с формирующими условиями и влияние депривации на процесс интеграции в общину.

Как свидетельствуют результаты полевого исследования, различение на теоретическом уровне структурного и культурного исключения, а также двух соответствующих депривационных механизмов, делают предложенную модель конверсии чувствительной к анализу смысловой направленности индивидов в процессе их интеграции в общину. Предположение о том, что наличествует связь культурного исключения с духовной депривацией и неинструментальным характером интеграции в общину, а структурного исключения с материальной депривацией и инструментальностью, в ряде случаев четко подтверждается. Однако для доказательства данной гипотезы требуется отдельное количественное исследование, нацеленное на классификацию случаев, а не описание феноменов. На данном же этапе исследования перед нами стояла задача на основе качественных данных описать сами изучаемые явления и их вариативность.

Существенным ограничением применяемого нами метода биографического интервью оказалось то, что реконструировать переживание материальной или духовной депривации в тех случаях, когда конверсия произошла более 10-20 лет назад, достаточно сложно. Кроме того, обнаруженный смешанный тип, в котором одновре- 
менно сочетаются два типа лишения, либо не наблюдаются прямые связи с соответствующим типом депривации, требует дальнейшего изучения.

Причины и обстоятельства формирования первичной предрасположенности к восприятию буддизма, как правило, относящиеся к детству, подростковому возрасту, на материалах наших интервью практически невозможно раскрыть - это требует более тонкого, чем социологический, инструментария. В силу этого мы не объясняем, а только отмечаем наличие такой направленности. Причем в неинструментальном типе она с большей легкостью может быть зафиксирована и отчасти реконструирована, поскольку данная область тематизирована самим информантом и в репрезентации личной истории она вносит существенный вклад в выстраивание нарратива, задавая вектор повествования. В случае инструментального типа конверсии мы часто имеем дело с реинтерпретацией личной истории постфактум. Информантами используется определенная сетка категорий, соответствующая буддийскому мировоззрению, что позволяет им видеть в истории своей жизни отдельные «знаки», случаи, связанные с опытом «прошлых жизней», действие закона кармы и проч. Таким образом, в неинструментальном типе направленность на буддизм скорее воспринимается информантом как определенная потребность, интерес и описывается как необъяснимая для него данность, а в инструментальном - формируется в процессе реинтерпретации личной истории и выполняет объяснительную функцию.

Можно утверждать, что направленность на буддизм является достаточно устойчивым феноменом в сознании наших информантов. Переживание периодов жизненных трудностей не всегда подталкивают к реализации этого интереса и к конверсии. Однако условием конверсии является наличие этих трудностей. Значимую роль также играет наличие друзей-буддистов или значимых других, которые могут активно не воздействовать в плане обращения, но создают определенный фон - положительное отношение, которое в итоге и приводит к конверсии.

Важным обнаружением оказалось то, что инструментальность не ограничивается только этапом интеграции в религиозную общину. Она может играть существенную роль и после завершившейся конверсии, становясь своего рода «профессионализацией». Это явление не ограничивается только односторонним использованием благ и ресурсов организации индивидом - вернее говорить об имеющей место конвертации различного рода капиталов (социального, экономического, культурного, символического), что предоставляет индивиду возможность для социальной мобильности. Причём инструментальность в момент активного обращения могла являться и не ведущим мотивом, но основывалась на воодушевлении, энтузиазме, определяемых не меркантильными аспектами, а своего рода предприимчивостью.

Отдельного изучения заслуживает поисковая религиозность, её яркие образцы сложно вписываются в модель социального механизма религиозной конверсии. Изза непрекращающегося религиозного поиска индивиды выходят за нормативные рамки буддизма данной школы, становясь своего рода маргиналами.

Ставя вопрос о решающем влиянии на конверсию психологических или социально-экономических факторов, необходимо учитывать их пересечение и общий социокультурный контекст. Как показывают результаты, с изменением общих экономических условий меняется и содержание инструментального типа конверсии, равно как и изменения в духовной сфере - трансформация религиозного рынка, его регулирование со стороны государства и изменяющиеся духовные потребности ин- 
дивидов - оказывают влияние на характер «незаинтересованной» конверсии. Кроме того, чувствительность самой религиозной организации к изменениям и её гибкость играют немаловажную роль.

\section{Научная литература}

Баранников А.С. Духовная (персональная) депривация: феноменологическое содержание, последствия, особенности диагностики и помощи // Развитие личности, 2010. № 4. С. 52-81.

Дивисенко К.С., Исаева В.Б. Типология обращения в западный буддизм в контексте концепции социального механизма религиозной конверсии // Научный результат, 2020. Т. 6. № 3. http://rrsociology.ru/journal/rubric/28/ (дата обращения: 20.10.2020).

Исаева В.Б. Социологические исследования религиозной конверсии в зарубежной научной традиции: классические концептуальные модели // Научное обозрение. Серия 2. Гуманитарные науки, 2013. № 6. С. 28-36.

Исаева В.Б. Теория депривации как инструмент изучения нетрадиционной религиозности // Социологические исследования, 2019. № 9. С. 39-50.

Рождественская Е.Ю. Биографический метод в социологии. Москва: Издательский дом Высшей школы экономики, 2012. $381 \mathrm{c}$.

Ясин М. Психологические исследования религиозной мотивации // Государство, религия, церковь в России и за рубежом, 2016. № 4. C. 51-67. DOI: 10.22394/2073-7203-2016-34-4-51-67.

Ярошенко С.С. О возможностях применения теории андеркласса в России // Социологические исследования, 2019. № 9. С. 28-38.

Ярошенко С.С. Синдром бедности // Социологический журнал, 1994. № 2. С. 43-50.

Cherry S.M., Budak K., Ramos A.I. Latina/o Conversion and Miracle-seeking at a Buddhist Temple // International Journal of Latin American Religions, 2018. № 2. P. 50-71.

Glock C.Y. The Role of Deprivation in the Origin and Evolution of Religious Groups //Religion and Social Conflict / Ed. by Lee R., Marty M. E. 1964. N-Y.: Oxford University Press, P. 24-36.

Gooren H. Religious Conversion and Disaffiliation: tracing patterns of change in faith Practices. Palgrave Macmillan. 2010. $181 \mathrm{p}$.

Gordon-Finlayson A., Daniels M. Westerners converting to Buddhism: an Exploratory Grounded Theory Investigation // Transpersonal Psychology Review, 2008. Vol. 12. № 1. P. 100-119.

Inglehart R., Norris P. Sacred and Secular: Religion and Politics Worldwide. N-Y.: Cambridge University Press.2004. 348 p.

Jindra I.W. A New Model of Religious Conversion: beyond Network Theory and Social Constructivism. Boston: Brill, 2014. 228 p.

Lofland J., Stark R. Becoming a world saver: a theory of conversion to a deviant perspective // American Sociological Review, 1965. Vol. 34. № 3. P. 862-875.

Magnone E. Analysis of Scholarly Communication Activities in Buddhism and Buddhist Studies // Information, 2015. Vol. 6. № 2. P. 162-182.

Niebuhr H.R. The Social Sources of Denominationalism. New-York: World Publishing, 1957. 316 p.

Prebish C. Studying the Spread and Histories of Buddhism in the West: The Emergence of Western Buddhism as a New Subdiscipline within Buddhist Studies // Westward Dharma: Buddhism Beyond Asia / ed. by C. Prebish, M. Baumann, USA: University of California Press, 2002. P. 66-81.

Stark R. The Triumph of Faith: Why the World is More Religious Than Ever. Wilmington, Delaware: ISI Books, 2015. 272 p.

Stark R. Class, Radicalism and Religious Involvement in Britain // American Sociological Review, 1964.Vol. 29. P. 698-706.

Stark R., Bainbridge W.S. A Theory of Religion. New Jersey: Rutgers University Press, 1996. 386 p.

Stolz J. Explaining religiosity: towards a unified theoretical model // The British Journal of Sociology, 2009. Vol. 60. № 2. P. 345-376.

Stolz J. Opening the Black Box. How the Study of Social Mechanisms Can Benefit from the Use of 
Explanatory Mixed Methods // Analyse and Kritik, 2016. № 1. P.257-285.

Wilson B.R. Sects and Society: a Sociological Study of the Elim Tabernacle, Christian Science, and

Christadelphians. Berkeley, Los Angeles: University of California Press, 1961. 397 p.

Yasin M. Psychological Studies of Religious Motivation // Gosudarstvo, religiia, tserkov' v Rossii i za rubezhom, 2016. Vol. 34 (4). P. 50-66.

YüD. S. Buddhist conversion in contemporary world//The Oxford Handbook of Religious Conversion/ edited by L. R. Rambo, C. E. Farhadian, Oxford University Press, 2014. P. 465-487.

Isaeva, Valentina B. and Konstantin S. Divisenko

\section{Material and Spiritual Deprivation as Factors of Religious Conversion (Western Buddhism Example)}

DOI: $10.33876 / 2311-0546 / 2021-3 / 244-260$

The article examines the influence of material and spiritual deprivation on religious conversion on the example of Western Buddhism. The significance of deprivation processes for religiosity is discussed in the light of the association between deprivation and religiosity, current debates about the methodology of religious conversion research, and the studies of Buddhism in new sociocultural areas. The research studies the biographies of the followers of Diamond Way Buddhism, one of the most widespread varieties of Western Buddhism in Russia - a variant of Tibetan Buddhism, oriented to the needs of the Western European audience. F. Schütze's narrative analysis was adapted to the objectives of the study and used as the primary methodological tool. The article presents the analysis of biographical interviews with the members of Buddhist communities conducted in 2018-2019 in St. Petersburg, Arkhangelsk, Severodvinsk, and Moscow. Examination of the biographical materials showed that initial interest in Buddhism is a necessary condition for conversion, in addition to experiencing structural and cultural deprivations. The theoretical model we employed distinguished between material and spiritual deprivation and the two corresponding types of integration into the Buddhist community: instrumental and non-instrumental. This allowed us to reconstruct the phenomenology of these types in connection with the experienced deprivation basing on empirical material. It was found that "instrumentalism" (orientation towards the material resources of the community) manifests itself not only at the stage of entering the community but also persists in the future as "professionalization" in Buddhism. "Non-instrumentality" seeks to redefine the foundations of one's worldview in order to cope with hardships by finding answers to existential questions and, eventually, to restore subjective well-being.

Keywords: material deprivation, spiritual deprivation, instrumentality, non-instrumentality, social exclusion, religious conversion, Western Buddhism

For Citation: Isaeva, V.B., Divisenko K.S. 2021. Material and Spiritual Deprivation as Factors of Religious Conversion (Western Buddhism Example). Herald of Anthropology (Vestnik Antropologii) 3: 244-260.

Author Info: Isaeva, Valentina B. - PhD in sociology, Associate Researcher, Sociological Institute of the Russian Academy of Sciences - Branch of the Federal Center of Theoretical and applied Sociology of the Russian Academy of Sciences (St. Petersburg, RF). E-mail: vbisaeva@gmail.com

Divisenko Konstantin S. - PhD in sociology, Senior Researcher, Sociological Institute of the Russian Academy of Sciences - Branch of the Federal Center of Theoretical and applied Sociology of the Russian Academy of Sciences (St. Petersburg, RF). E-mail: k.divisenko@socinst.ru 


\section{References}

Barannikov, A.S. 2010. Dukhovnaia (personal'naia) deprivatsiia: fenomenologicheskoe soderzhanie, posledstviia, osobennosti diagnostiki i pomoshchi [Spiritual (personal) deprivation: phenomenological content, consequences, features of diagnosis and assistance]. Razvitie lichnosti 4: 52-81.

Cherry, S. M., K. Budak, and A.I. Ramos. 2018. Latina/o Conversion and Miracle-seeking at a Buddhist Temple. International Journal of Latin American Religions 2: 50-71.

Divisenko, K.S., and V.B. Isaeva. 2020. Tipologiia obrashcheniia v zapadnyi buddizm v kontekste kontseptsii sotsial'nogo mekhanizma religioznoi konversii [Typology of conversion to Western Buddhism in the context of the concept of the social mechanism of religious conversion]. Nauchnyi rezul 'tat 6 (3). http://rrsociology.ru/journal/issue/3-25-2020/.

Glock, C.Y. 1964. The Role of Deprivation in the Origin and Evolution of Religious Groups. Religion and Social Conflict, edited by R. Lee, M.E. Marty, 24-36. N.-Y.: Oxford University Press.

Gooren, H. 2010. Religious Conversion and Disaffiliation: tracing patterns of change in faith Practices. Palgrave Macmillan.

Gordon-Finlayson, A., Daniels, M. 2008. Westerners converting to Buddhism: an Exploratory Grounded Theory Investigation. Transpersonal Psychology Review 12 (1): 100-119.

Isaeva, V. B. 2013. Sotsiologicheskie issledovaniia religioznoi konversii v zarubezhnoi nauchnoi traditsii: klassicheskie kontseptual'nye modeli [Sociological studies of religious conversion in the foreign scientific tradition: classical conceptual models]. Nauchnoe obozrenie. Seriia 2. Gumanitarnye nauki 6: 28-36.

Isaeva, V. B. 2019. Teoriia deprivatsii kak instrument izucheniia netraditsionnoi religioznosti [The theory of deprivation as a tool for studying non-traditional religiosity]. Sotsiologicheskie issledovaniia 9: 39-50.

Inglehart, R., Norris, P. 2004. Sacred and Secular: Religion and Politics Worldwide. N.-Y.: Cambridge University Press.

Jindra, I.W. 2014. A New Model of Religious Conversion: beyond Network Theory and Social Constructivism. Boston: Brill.

Lofland, J., Stark R. 1965. Becoming a world saver: a theory of conversion to a deviant perspective. American Sociological Review 34 (3): 862-875.

Magnone, E. 2015. Analysis of Scholarly Communication Activities in Buddhism and Buddhist Studies. Information 6 (2): 162-182.

Niebuhr, H.R. 1957. The Social Sources of Denominationalism. New-York: World Publishing.

Prebish, C. 2002. Studying the Spread and Histories of Buddhism in the West: The Emergence of Western Buddhism as a New Subdiscipline within Buddhist Studies. Westward Dharma: Buddhism Beyond Asia, ed. by C. Prebish, M. Baumann, 66-81. USA: University of California Press.

Rozhdestvenskaia, E.Yu. 2012. Biograficheskii metod v sotsiologii [Biographical Method in Sociology]. Moscow: Izdatel'skii dom Vysshei shkoly ekonomiki.

Stark, R. 2015. The Triumph of Faith: Why the World is More Religious Than Ever. Wilmington, Delaware: ISI Books.

Stark, R. 1964. Class, Radicalism and Religious Involvement in Britain. American Sociological Review 29: 698-706.

Stark, R., W.S. Bainbridge. 1996. A Theory of Religion. New Jersey: Rutgers University Press.

Stolz, J. 2009. Explaining religiosity: towards a unified theoretical model. The British Journal of Sociology 60 (2): 345-376.

Stolz, J. 2016. Opening the Black Box. How the Study of Social Mechanisms Can Benefit from the Use of Explanatory Mixed Methods. Analyse and Kritik 1: 257-285.

Wilson, B.R. 1961. Sects and Society: a Sociological Study of the Elim Tabernacle, Christian Science, and Christadelphians. Berkeley, Los Angeles: University of California Press.

Yasin, M. 2016. Psikhologicheskie issledovaniia religioznoi motivatsii [Psychological studies of religious motivation]. Gosudarstvo, religiia, tserkov'v Rossii i za rubezhom 4: 51-67. DOI: 
10.22394/2073-7203-2016-34-4-51-67.

Yaroshenko, S. S. 2019. O vozmozhnostiakh primeneniia teorii anderklassa v Rossii [About the possibilities of applying the theory of the underclass in Russia]. Sotsiologicheskie issledovaniia 9: 28-38. Yaroshenko, S. S. 1994. Sindrom bednosti [The poverty syndrome]. Sotsiologicheskii zhurnal 2: 43-50.

Yü D.S. 2014. Buddhist conversion in contemporary world. The Oxford Handbook of Religious Conversion, edited by L. R. Rambo, C.E. Farhadian, 465-487. Oxford University Press. 